\title{
Thermally induced pore water pressure of reconstituted London clay
}

\author{
Sihua Chen $^{1, *}$, Lidija Zdravkovic ${ }^{1}$, and J. Antonio H. Carraro ${ }^{1}$ \\ ${ }^{1}$ Imperial College London, Department of Civil and Environmental Engineering, SW7 2AZ, UK
}

\begin{abstract}
Different forms of thermo-active structures have been proposed as a way of making use of the ground temperature to achieve renewable low-carbon heating and cooling in civil engineering construction. Such structures comprise piles, retaining walls or tunnel linings, and are used both as structural components and as conduits for utilising geothermal energy. In the scenario of the underground space in London, it is the thermo-active piles that have received most attention. However, little experimental evidence exists on the thermal behaviour of London clay to aid the design of thermo-active structures. This paper presents advanced laboratory testing on the reconstituted London clay to characterise the effect of temperature on its mechanical behaviour. Particular emphasis is given to thermally induced pore water pressures, as their evolution is not well understood. Tests are conducted in a temperature-controlled isotropic cell developed at Imperial College London. The emphasis of the current paper is on the temperature-based calibrations of different transducers. Soil specimens are isotropically consolidated and then subjected to undrained heatingcooling in the temperature range of 21 to $37^{\circ} \mathrm{C}$. Results obtained are compared with an existing laboratory study on another type of clay.
\end{abstract}

\section{Introduction}

The design of thermo-active structures depends on the thermo-hydro-mechanical behaviour of the surrounding soil under temperature changes imposed by their operation $[1,2]$. Below a certain depth (usually $10-15 \mathrm{~m}$, depending on the local climate), the soil temperature remains nearly constant throughout the year $[3,4]$. Therefore, there is a difference in temperature between the ground and structures above. The ground can act as a heat source during the winter and as a heat sink during the summer. The interface between the thermo-active structures and the surrounding soil is subjected to heatingcooling cycles up to $40{ }^{\circ} \mathrm{C}$ [5-9]. Abuel-Naga et al. [10] found that normally consolidated and lightly overconsolidated soft Bangkok clay contracted upon heating, while heavily overconsolidated samples dilated. In addition, the thermally induced pore water pressure was affected by the magnitude of the applied mean effective stress and stress history. A range of results for other clays is presented by Hueckel \& Baldi [11] (Pontida clay, Pasquasia clay), Sultan et al. [12] (Boom clay), Cekerevac \& Laloui [13] (kaolin), and Martinez-Calonge [14] (London clay), with often contradicting evidence on the effect of temperature on clays' mechanical properties. The findings in this paper are part of a broader research that aims to further characterise the behaviour of London clay under heating-cooling cycles.

\section{Methodology}

\subsection{Testing equipment}

Undrained heating tests on specimens of reconstituted London clay are performed in a temperature-controlled isotropic apparatus (Figure 1) developed in the Geotechnics Laboratory at Imperial College London. Distilled water inside the stainless steel cell (Figure 1a) supplies a confining pressure of up to $800 \mathrm{kPa}$. Three 150 $\mathrm{W}$ cartridge heaters (Figure 1b) are installed in the bottom plate and another three heaters are placed in the top plate, capable of raising the temperature of water surrounding the specimen up to $85^{\circ} \mathrm{C}$. For the purpose of investigating the possible effect of thermo-active structures, temperature of the soil specimen is raised up to $40{ }^{\circ} \mathrm{C}$. Temperature sensors (Figure $1 \mathrm{c}$ ) are installed next to each heater and inside the confining fluid at the same level as the mid-height of the specimen to monitor the temperature throughout each test. Temperature of the soil specimen at the bottom, mid-height and top was monitored in trial tests by Martinez-Calonge [14]. The maximum difference in temperature at the monitoring point of the cell water and at the three locations of the soil specimen was shown to be only $0.15{ }^{\circ} \mathrm{C}$. Therefore, the temperature of the soil specimen can be represented by the temperature measured by the sensor inside the confining fluid [14]. The isotropic cell is insulated by several layers of bubble wrap, placed around the cell in a controlled pattern to ensure uniformity of insulation between different tests. Specimens (Figure 1 f) with $50 \mathrm{~mm}$ diameter and $100 \mathrm{~mm}$ in height can be tested in this apparatus. Water flowing in and out of the

\footnotetext{
* Corresponding author: sihua.chen16@imperial.ac.uk
} 
cell is monitored using cell pressure air/water interface. Pore water pressure is monitored from a transducer located in the back pressure line at the base of the cell and also using a mid-plane pore pressure transducer (Figure 1 g) that is located at the mid-height of the soil specimen. The TRIAX software [15] is used to digitally control, monitor and record pressures, load and displacement.

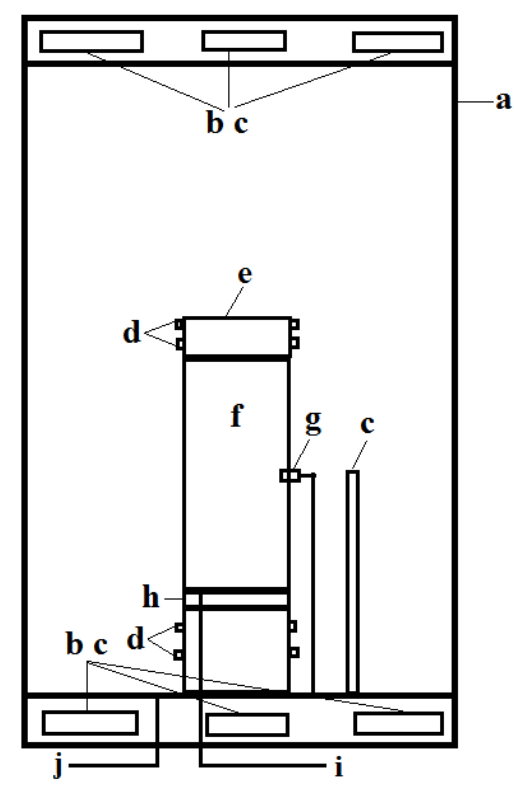

Fig. 1. Schematic view of temperature-controlled isotropic apparatus. (a) stainless steel chamber; (b) heater; (c) temperature sensor; (d) O-ring; (e) topcap; (f) soil specimen; (g) mid-plane pore pressure probe; (h) porous disc; (i) to back pressure volume gauge; $(\mathrm{j})$ to cell pressure volume gauge

\subsection{Materials}

London clay (plasticity index $=45 \%$ ), taken from a borehole near the Victoria and Albert museum at 11-12 m depth, was used in the experimental programme. The mineralogy composition of the soil was evaluated using X-ray diffraction [14]. The majority of the soil is smectite $(30.2 \%)$, followed by illite $(26.3 \%)$, quartz $(22.5 \%)$, chlorite $(7.4 \%)$, feldspars $(6.1 \%)$, kaolinite $(4.8 \%)$ and dolomite $(2.7 \%)$. The clay is ground into dry powder, mixed with water at 1.25 times the water content at liquid limit [16] and consolidated under the effective vertical stress of $200 \mathrm{kPa}$ for three weeks in a consolidometer, leading to a London clay 'cake' with $225 \mathrm{~mm}$ in diameter, $130 \mathrm{~mm}$ in height and water content of $35 \%$.

\section{Calibration of instrumentation}

In the thermal testing of soils, several issues must be taken into consideration to ensure the quality of the tests. Firstly, changes in physical quantities due to temperature may be very small, close to the resolution and accuracy of the instrumentation. Secondly, the instrumentation output may be temperature sensitive. It is important to distinguish the soil response and the response of the instrumentation due to temperature variations. Lastly, tests last for a long time and a small leakage in the system can lead to considerable errors. To address these issues, long-term monitoring and temperature-based calibrations have to be performed.

Calibrations of the instrumentation have been performed under room temperature (i.e. $21^{\circ} \mathrm{C}$ ) following standard calibration procedures as recommended by Head [17]. Back pressure and cell pressure transducers are connected to the cell via steel tubing to minimise system compliance and located at a distance from the cell to minimise the amount of heat transferred to the instrumentation. During testing, it is possible that the heated water will enter the pressure transducer and influence the pressure readings. In order to obtain calibration factors of the instrumentation under different temperature levels, the back pressure transducer was connected to the triaxial cell and the Budenburg dead weight calibrator at the same time, using a $T$ valve. Water in the triaxial cell was heated and allowed to reach the pressure transducer as in the case of real tests. Back pressure transducer was then loaded from $0 \mathrm{kPa}$ to 600 $\mathrm{kPa}$ using the Budenburg dead weight calibrator for three loading and unloading cycles, with 72 data points obtained for plotting calibration curves at each temperature level. Calibration factors were estimated up to four decimal places based on the analysis of the calibration data. The same calibration procedure was applied to the cell pressure transducer. For back pressure transducer, if a single calibration factor is used for temperature ranging from 21 to $60{ }^{\circ} \mathrm{C}$, the maximum error for the combined data is $0.4 \%$, which is close to the maximum error of the data at a single temperature level (Table 1). Thus, changing the temperature from 21 to 60 ${ }^{\circ} \mathrm{C}$ does not affect the performance of back pressure transducer. The same applies to the cell pressure transducer.

Table 1. Calibration curves of back and cell pressure transducers under different temperature levels

\begin{tabular}{|c|c|c|c|}
\hline & $\begin{array}{c}\text { Temperature } \\
\left({ }^{\circ} \mathrm{C}\right)\end{array}$ & Calibration curve & $\begin{array}{c}\text { Max } \\
\text { error } \\
(\mathrm{kPa} \text {; } \\
\%)\end{array}$ \\
\hline \multirow{4}{*}{$\begin{array}{c}\text { Back } \\
\text { pressure } \\
\text { transducer }\end{array}$} & 21 & $y=0.0189 x+1.24 *$ & $3.9 ; 0.8$ \\
\hline & 40 & $y=0.0189 x+4.19$ & $1.4 ; 0.3$ \\
\hline & 60 & $y=0.0190 x+4.55$ & $1.6 ; 0.4$ \\
\hline & $21-60$ & $y=0.0189 x+4.75$ & $4.2 ; 0.8$ \\
\hline \multirow{4}{*}{$\begin{array}{c}\text { Cell } \\
\text { pressure } \\
\text { transducer }\end{array}$} & 21 & $y=-0.0188 x+4.24$ & $2.0 ; 0.4$ \\
\hline & 40 & $y=-0.0188 x+8.28$ & $1.1 ; 0.2$ \\
\hline & 60 & $y=-0.0189 x+8.20$ & $1.6 ; 0.3$ \\
\hline & $21-60$ & $y=-0.0189 x+7.86$ & $2.3 ; 0.4$ \\
\hline
\end{tabular}

* $\mathrm{x}$ and $\mathrm{y}$ represent the output electrical signal of instrumentation in $\mathrm{uV}$ and pressure in $\mathrm{kPa}$, respectively. 
During the test, mid plane pore pressure probe is placed inside the triaxial cell and it may also be affected by the heated soil specimen around it. Having proved that calibration factors of back and cell pressure transducers are insensitive to changes in temperature, calibration curves of mid plane pore pressure probe are obtained by using readings from back pressure transducer as a reference (Table 2).

Table 2. Calibration curves of mid plane pore pressure probe under different temperature levels

\begin{tabular}{|c|c|c|}
\hline $\begin{array}{c}\text { Temperature } \\
\left({ }^{\circ} \mathrm{C}\right)\end{array}$ & Calibration curve & Max error $(\mathrm{kPa} ; \%)$ \\
\hline 21 & $\mathrm{y}=-0.0163 \mathrm{x}+25.87^{*}$ & $1.5 ; 0.3$ \\
\hline 37.5 & $\mathrm{y}=-0.0169 \mathrm{x}+27.08$ & $1.7 ; 0.3$ \\
\hline 40 & $\mathrm{y}=-0.0170 \mathrm{x}+29.01$ & $0.8 ; 0.2$ \\
\hline 60 & $\mathrm{y}=-0.0178 \mathrm{x}+28.98$ & $2.1 ; 0.4$ \\
\hline $21-60$ & $\mathrm{y}=-0.0168 \mathrm{x}+32.74$ & $38.6 ; 8.0$ \\
\hline
\end{tabular}

${ }^{*} \mathrm{x}$ and $\mathrm{y}$ represent the output electrical signal of mid-plane pore pressure probe in $\mathrm{uV}$ and pressure in $\mathrm{kPa}$, respectively.

By plotting slopes of calibration curves at 21, 37.5, 40 and $60{ }^{\circ} \mathrm{C}$ against corresponding temperature levels (Figure 2), calibration factors under temperature levels from 21 to $60{ }^{\circ} \mathrm{C}$ can be estimated based on a linear interpolation. If the calibration factor at $21^{\circ} \mathrm{C}$ is used when the cell water temperature is $60{ }^{\circ} \mathrm{C}$, maximum error in the pressure measurement of mid-height probe is $8 \%$, equivalent to $63 \mathrm{kPa}$ when the pressure is $700 \mathrm{kPa}$. Thus, changing of temperature in the range of 21 to $60^{\circ} \mathrm{Caffects}$ the performance of mid-plane pore water pressure probe. Temperature-based calibration factors should be applied to obtain reliable readings.

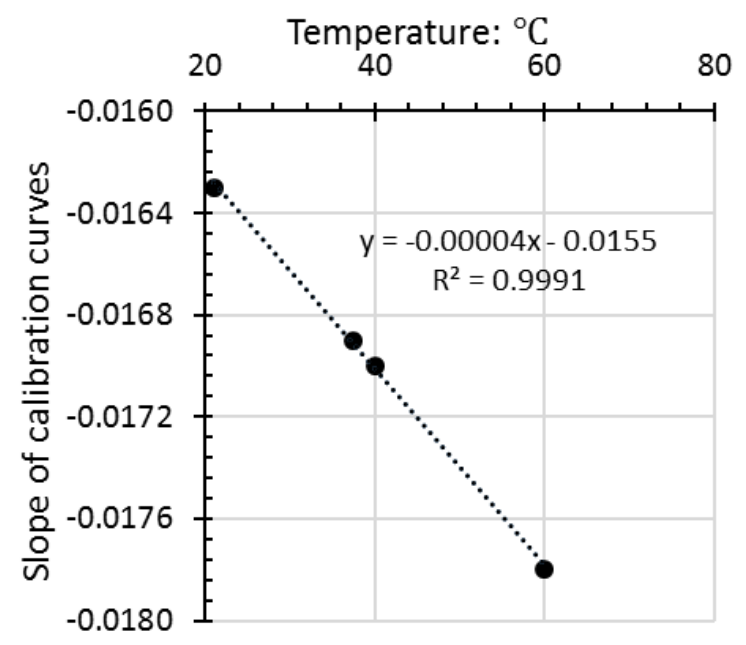

Fig. 2. Regression curve of calibration factors of mid-plane pore pressure probe under different temperature levels

\section{Testing procedures}

A trial test has been performed on reconstituted London clay. Soil specimen trimmed from London clay 'cake' as described in section 2.2 was used for the testing programme. The testing procedures are summarised in the following sections $[14,18]$.

\subsection{Specimen setup}

Distilled water was flushed through drainage lines before testing. Porous disks were saturated for at least 30 minutes. Specimen was installed with filter paper side drains and porous discs on top and bottom. Latex membrane with thickness of $0.3 \mathrm{~mm}$ was used in this test as no significant degradation of the membrane was observed in trial tests in the temperature range of 21 to 37 ${ }^{\circ} \mathrm{C}$.

\subsection{Initial mean effective stress stage}

A cell pressure similar to the maximum value that the sample had experienced in the past was applied with drainage lines closed. For the reconstituted London clay in this test, a cell pressure of $200 \mathrm{kPa}$ was applied. The increase in back pressure was monitored until it became stable. The initial mean effective stress was recorded.

\subsection{Saturation stage}

Valves to back pressure line were opened. Cell pressure and back pressure were increased at a rate of 50 $\mathrm{kPa} / \mathrm{h}$, maintaining a constant mean effective stress, until a back pressure of $300 \mathrm{kPa}$ was reached. The pressure values were held for 48 hours before a B-value test was performed. If the B-value was below 0.98 [18], cell pressure and back pressure would be further increased until the B-value reached at least 0.98 .

\subsection{Compression and creep}

Cell pressure was increased at a rate of $1 \mathrm{kPa} / \mathrm{h}$ until the mean effective stress reached $150 \mathrm{kPa}$. The pressure values were held for enough time until the change in volume of the specimen was smaller than $0.05 \%$ /day, as monitored by the back pressure volume gauge, whose rate of natural leakage was $0.025 \%$ /day and this was accounted for in calculation. The creep stage took 114 hours in this initial test.

\subsection{Undrained heating}

Valves to back pressure volume gauge were closed. The heating process was achieved in five increments, with $3{ }^{\circ} \mathrm{C}$ in every increment as shown in Figure 3. After the pore pressure has stabilised at each temperature increment, the temperature of water surrounding the soil specimen was increased to the next temperature level. The total time for heating was 6 hours. 


\subsection{Natural cooling}

After the temperature has reached $37^{\circ} \mathrm{C}$, heaters were turned off. The triaxial cell was cooled to $21^{\circ} \mathrm{C}$, which took 14 hours after removing insulation.

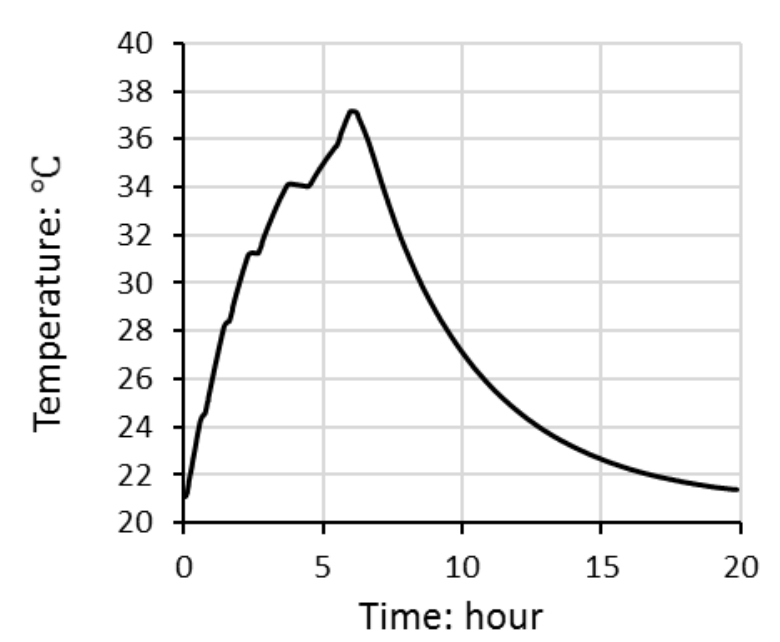

Fig. 3. Temperature-time path for undrained heating test on reconstituted London clay (cell water temperature measurements shown)

\section{Results}

Thermally induced pore water pressures measured from back pressure line and mid-plane pore pressure probe are shown in Figure 4. Pore water pressure was induced as the temperature was increased, due to the difference in the thermal expansion coefficients of water and soil particles [10]. Pore pressure from mid-plane pore pressure probe obtained with the calibration factor at $21{ }^{\circ} \mathrm{C}$ is shown in Figure 4a. Uncorrected pore water pressure measured by mid-plane probe was lower than that from back pressure line and only a small proportion of the difference $(3 \mathrm{kPa})$ was due to the elevation difference of the two pressure transducers. The deviation between the two readings increased with an increase in temperature and the maximum difference was $10 \mathrm{kPa}$. After temperaturebased calibration factors were applied to pore water pressure measured by mid-plane probe and the pressure due to elevation difference was accounted for, readings from two pressure transducers differed by less than $1 \mathrm{kPa}$ (Figure 4b). This result confirms that the stress state in the soil specimen was the same at two different elevations (i.e. at the base and mid-height level) when equilibrium stress state has been achieved with temperature. The test can be treated as an element test, as it is typically assumed in conventional triaxial testing.

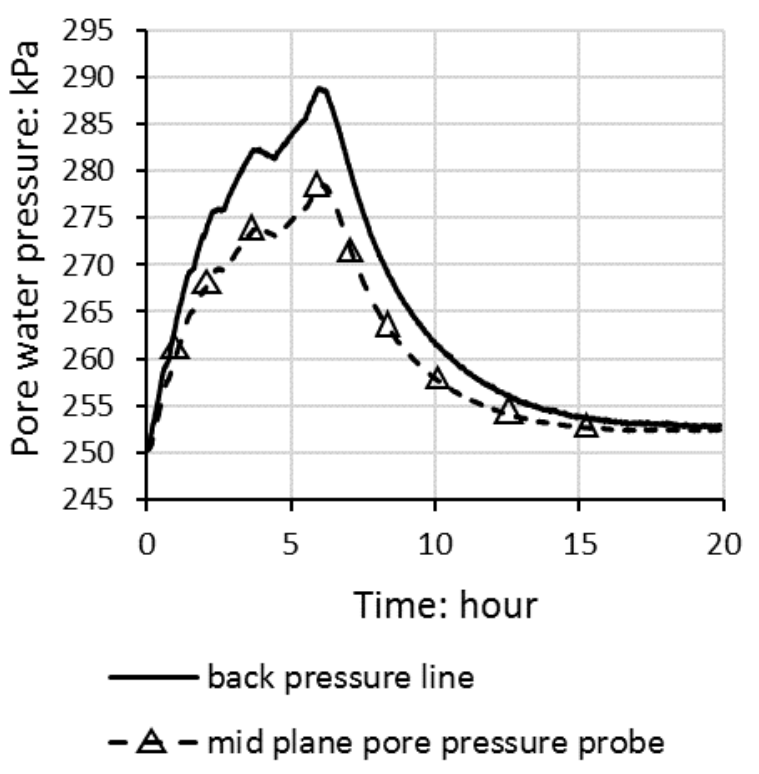

(a)

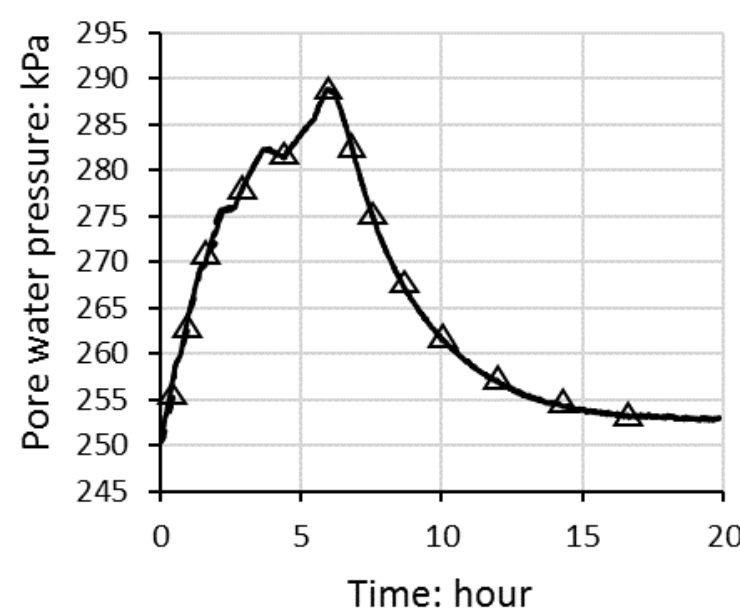

— back pressure line

- $\Delta$ - mid plane pore pressure probe (corrected for
temperature effects)

(b)

Fig. 4. Thermally induced pore water pressure (a) using calibration factors at $21^{\circ} \mathrm{C}$; (b) using temperature-based calibration factors

A maximum excess pore water pressure of $38 \mathrm{kPa}$ was induced when the soil specimen was heated under undrained condition from 21 to $37{ }^{\circ} \mathrm{C}$ (Figure 5). Hysteresis in excess pore water pressure was observed in the heating-cooling process. Thermally induced pore water pressure was mostly reversible when the soil cooled down to room temperature. Similar behaviour was reported by Abuel-Naga et al. [10] on normally consolidated soft Bangkok clay, where the soil specimen was isotropically consolidated to $200 \mathrm{kPa}$ then heated under undrained condition. The magnitude of excess pore water pressure presented by Abuel-Naga et al. [10] was $35 \mathrm{kPa}$ when the soil was heated from 25 to $40{ }^{\circ} \mathrm{C}$. 


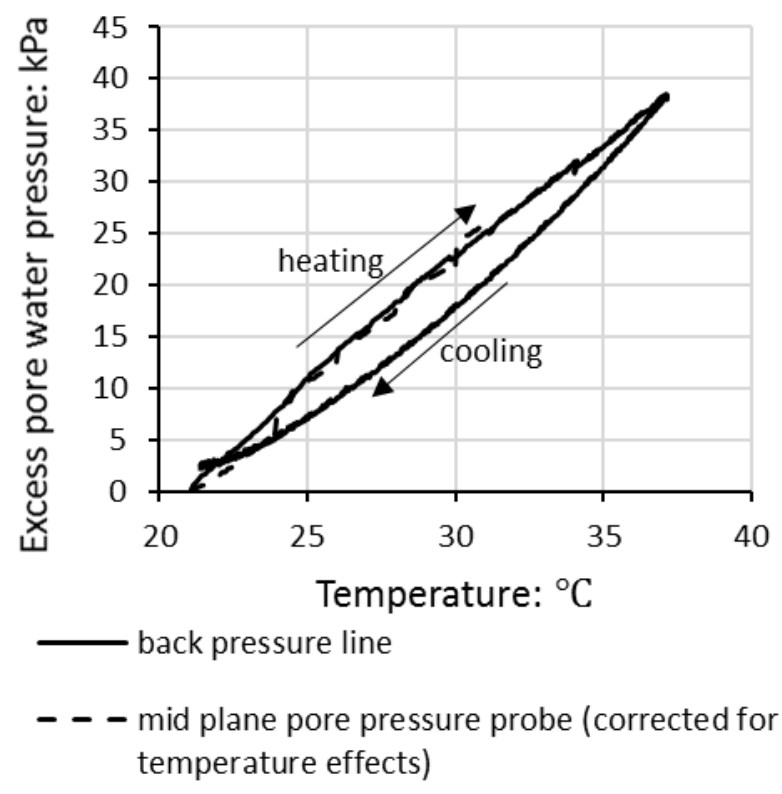

Fig. 5. Thermally induced excess pore water pressure

\section{Conclusion}

Proceeding from the previous work by Martinez-Calonge [14] on thermo-hydro-mechanical behaviour of London clay, improvements have been made on the temperaturecontrolled isotropic cell at Imperial College London Geotechnical Laboratory. Mid-plane pore pressure probe has been added to the cell and temperature-based calibration has been performed. The initial result on the undrained heating of reconstituted London clay showed that thermally induced pore water pressure at the base of the specimen and at the mid-height was practically the same, after temperature-based calibration factors were applied. For normally consolidated London clay specimen, thermally induced excess pore water pressure was reversible in the temperature range of 21 to $37^{\circ} \mathrm{C}$. Further tests will be performed on London clay following the same protocol to characterise thermally induced pore water pressure, focusing on the effect of thermal cycles, stress history and stress level, to aid the design of thermoactive structures.

This research is funded by the Chinese Scholarship Council. Mr. Steve Ackerley and Mr. Graham Keefe are acknowledged for their technical support with equipment.

\section{References}

1. K.A. Gawecka, D.M.G. Taborda, D.M. Potts, W. Cui, L. Zdravkovi, M.S.H. Kasri, Proc. Inst. Civ. Eng. Geotech. Eng., 170, 201-219 (2017)

2. E. Sailer, D.M.G.Taborda, L. Zdravkovic, D.M. Potts, 9th Eur. Conf. Numer. Methods Geotech. Eng., 741-749 (2018)

3. J. Busby, M. Lewis, H. Reeves, R. Lawley, Quarterly J. Eng. Geol. Hydrogeol., 42, 295-306 (2009).
4. D. Banks, An Introduction to Thermogeology: Ground Source Heating and Cooling (2012)

5. H. Brandl, Géotechnique, 56, 2, 81-122 (2006)

6. Y. Hamada, M. Nakamura, H. Kubota, Appl. Energy, 84, 2, 117-134 (2007)

7. C.J. Wood, H. Liu, S.B. Riffat, Géotechnique, 59, 3 , 287-290 (2009)

8. N. Yavari, A.M. Tang, J.M. Pereira, G. Hassen, Géotechique Lett., 4, 2, 119-124 (2014)

9. C. Li, G. Kong, H. Liu, H.M. Abuel-Naga, Can. Geotech. J. (2018)

10. H.M. Abuel-Naga, D.T. Bergado, A. Bouazza, Eng. Geol., 89, 1-2, 144-154 (2007)

11. T. Hueckel, G. Baldi, ASCE J. Geotech. Geoenviron. Eng., 116 (12), 1778-1796 (1990)

12. N. Sultan, P. Delage, Y.J. Cui, Eng. Geol., 64, 2-3, 135-145 (2002)

13. C. Cekerevac, L. Laloui, Int. J. Numer. Anal. Methods Geomech., 28, 3, 209-228 (2004)

14. D. Martinez-Calonge, Experimental investigation of the thermo-mechanical behaviour and thermal properties of London clay. $\mathrm{PhD}$ thesis. Imperial College London, United Kingdom (2017)

15. D. Toll, In: B. Kumar, B.H.V. Topping, (eds.) Computing Developments in Civil and Structural Engineering, 237-242 (1999)

16. J.B. Burland, Géotechnique, 40, 3, 329-378 (1990)

17. K.H. Head, Manual of soil laboratory testing (1998)

18. ASTM D7181-11. Standard Test Method for Consolidated Drained Triaxial Compression Test for Soils 